\title{
Exploring Trends in EFL Students Theses from 2014 to 2018
}

\author{
Muhammad Affan Ramadhana ${ }^{1 *}$, Fatima ${ }^{2}$ \\ 1*, Akademi Teknologi Industri Dewantara Palopo, Indonesia \\ 2, Universitas Cokroaminoto Palopo, Indonesia \\ *affan@pustaka.my.id
}

\begin{abstract}
This study aims to explore the themes and methods most often applied by EFL students in their thesis. Sampling is done randomly by collecting theses submitted by students from five consecutive years $(2014-2018)$. The data obtained is entered into several tables and graphs, followed by several descriptions of the values contained in the table or graph. This research shows the increase and decrease of student interest regarding the selection of themes and methods they used in their theses. The most widely used theme is vocabulary, and the most frequently used research method is pre-experimental.
\end{abstract}

Keywords: thesis, EFL students, research theme, research method

\section{Introduction}

Research is scientific work written by students discussing a particular topic or field based on the results of a literature review written by experts, the results of field research, or the results of development (experiments). Students are guided by a minimum of two supervisors appointed by the relevant university. This guidance is intended to make the students' thesis quality results both in terms of content and delivery techniques. Research is also part of a deepening activity in science through writing activities for students at the end of the semester. In fact, because of the importance of this activity, the graduation or completeness of the final program is determined by the quality of their research report.

Research throughout the world at universities is one requirement for students who want to complete their studies. Every student must do that because by doing so, they can fulfill the requirements to get some titles that universities around the world have prepared. Not only overseas but in our country, students are also required to do the preparation and writing of final project reports, with the provisions seen in the guidebook for preparation and writing of final project reports in their respective faculties. Since students are academics, their lives on campus struggle with science day and night. Therefore, the learning orientation is that he will produce scientific work at least once during college. Students as academics will be considered as contributing to science when they write a thesis or thesis. The scientific work must be written referring to the results of the study.

Over the past decade, programs and scholars at Universitas Cokroaminoto Palopo have undergone this process and policy to date. Not only that, so far, there have been many graduates born from this university by carrying out this final research as a requirement and policy to get their degree.

The factor that significantly influences this research is the influence of the curriculum on campus during the last decade. Well, in the last decade, there have been two changes in the curriculum. Moreover, the last is the influence of the supervisor. Moreover, at that time, the supervisors from outside the campus were more dominant than those on campus. Those are some of the reasons that influence the existence of this research. 
Therefore, this research must also investigate the trends in selecting themes and titles and the most often and widely used methods between 2014 and 2018, especially in the Department of English Education at Universitas Cokroaminoto Palopo.

\section{Method}

To collect the data, first, the researcher took theses starting from 2014 to 2018 by using a sampling technique that is purposive sampling where the researcher sets certain categories. Second, the researcher looks for the title of the thesis theme and research method. Third, the researcher took all thesis themes about trends themed and research method. Fourth, the researcher looked at the title of the thesis, the year of the thesis is made, name of the student, ID number, name of the supervisor, themed raised, the method used, time and location, sampling of the research, and also instruments used by the thesis. The five researchers took and grouped all data per year according to the category.

The researcher grouped the data according to the themes obtained from the whole thesis. The data is divided into six based on themes: reading, writing, speaking, listening, grammar, and vocabulary. The data is also divided based on methods, namely, quantitative, qualitative, and mixed methods. The number of samples needed is only 50 samples. However, the researcher conducted a re-examination so that the number of samples currently is 52 theses. The researcher explained each data obtained about the differences and similarities between one data and another data.

\section{Results}

This study aims to find out and describe the types of themes that students often raise. This research also aims to describe methods, instruments, types of sampling taken by students from 2014 to 2018. This research runs and is carried out starting from the sampling process, where the intended sample is a thesis already available in the library with ten theses each year, namely from 2014 to 2018. As a result, the number of theses needed by researchers is 52 theses.

\section{Research Themes}

In learning English, several types of skills can be learned in the teaching and learning process. In some types of skills, there are still many students who do not understand and cannot understand the skill and vice versa. We can find several kinds of these skills in every meeting of the learning process and select themes or topics in the final semester, which is more precisely in the process of compiling scientific works (thesis). The following are the skills trends that are most used by students such as:

Students each year, six skill choices can be used each year, but in this study, researchers only specialize from 2014 to 2018 only. The number of theses discussed reading is 12 , speaking is 6 , writing is 11 , vocabulary is 19 , grammar is 2 , and listening is 2. From the results of these explanations, it can be concluded that the theme most often adopted by students is vocabulary. 


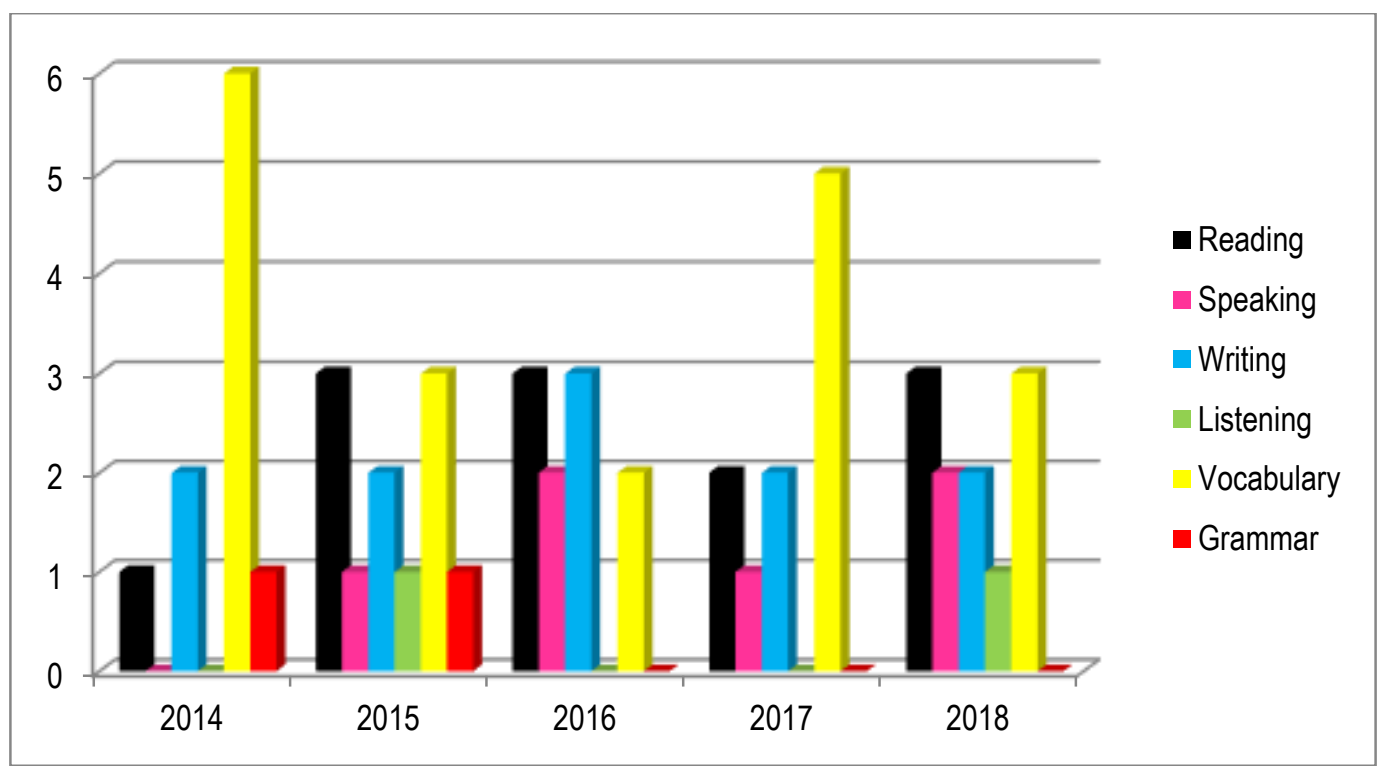

\section{Research Methods}

Figure 1. Research Themes

There are three main criteria of the method most often adopted by students. We can conclude that there were 38 theses used quantitative method, there were 11 theses used qualitative method, and there were one theses used mix method. So, it can be concluded that the method most often adopted by students is the Quantitative method.

The qualitative method is divided into phenomenology, ethnography, case studies, historical methods, and basic theoretical methods. The quantitative method is divided into descriptive, correlation, experimental, action research, and $\mathrm{RnD}$ (research and development). From the various types of research methods above, we can conclude that quantitative research is the research method that students most widely used to analyze their data. Students rarely use the mixed method.

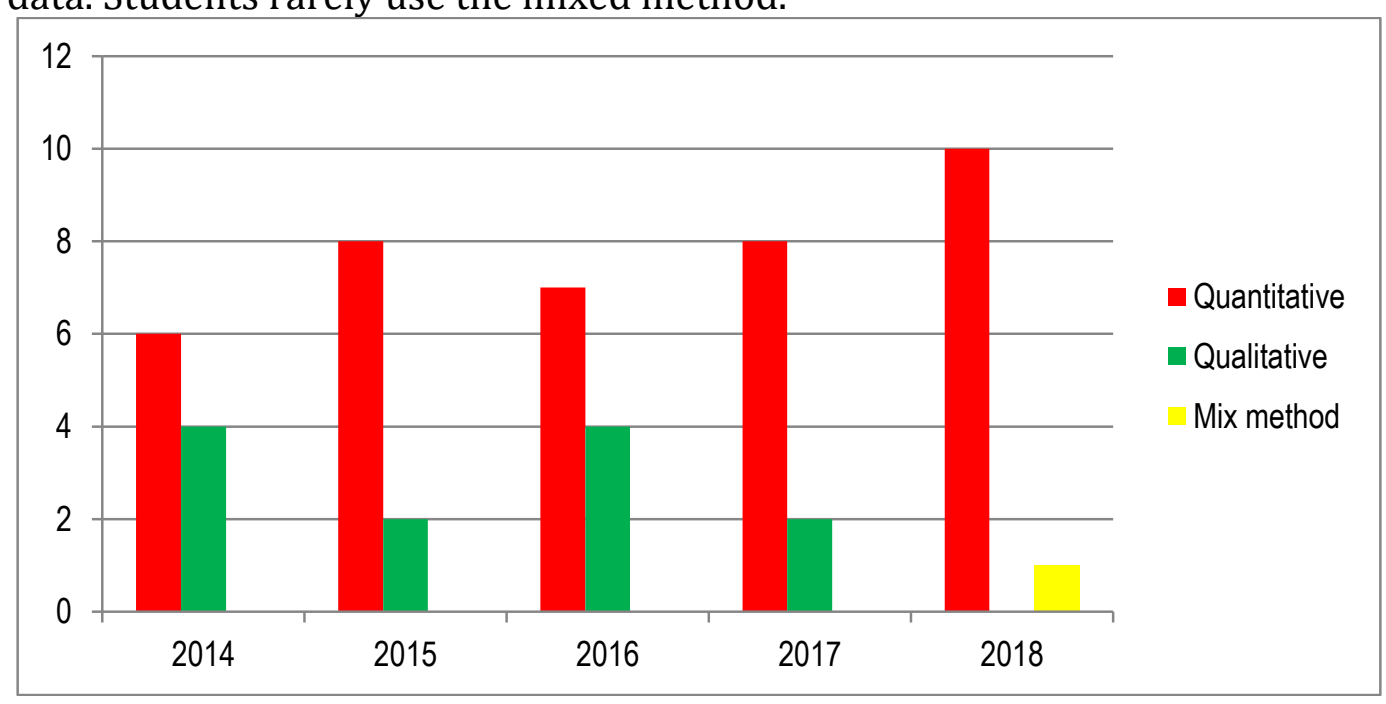

Figure 2. Research Methods

\section{Research Sampling}

Sampling is the process of taking or selecting elements from populations that are of the size of N. There are five categories and types in sampling selection for use in sampling. It can be seen that in the purposive sampling from 2014 to 2018, there were 8 . In the random sampling, there were 9, the cluster sampling amounted to 23 , and the 
total sampling amounted to 6 . Therefore, it can be concluded that the type of sampling most widely used by students is cluster random sampling.

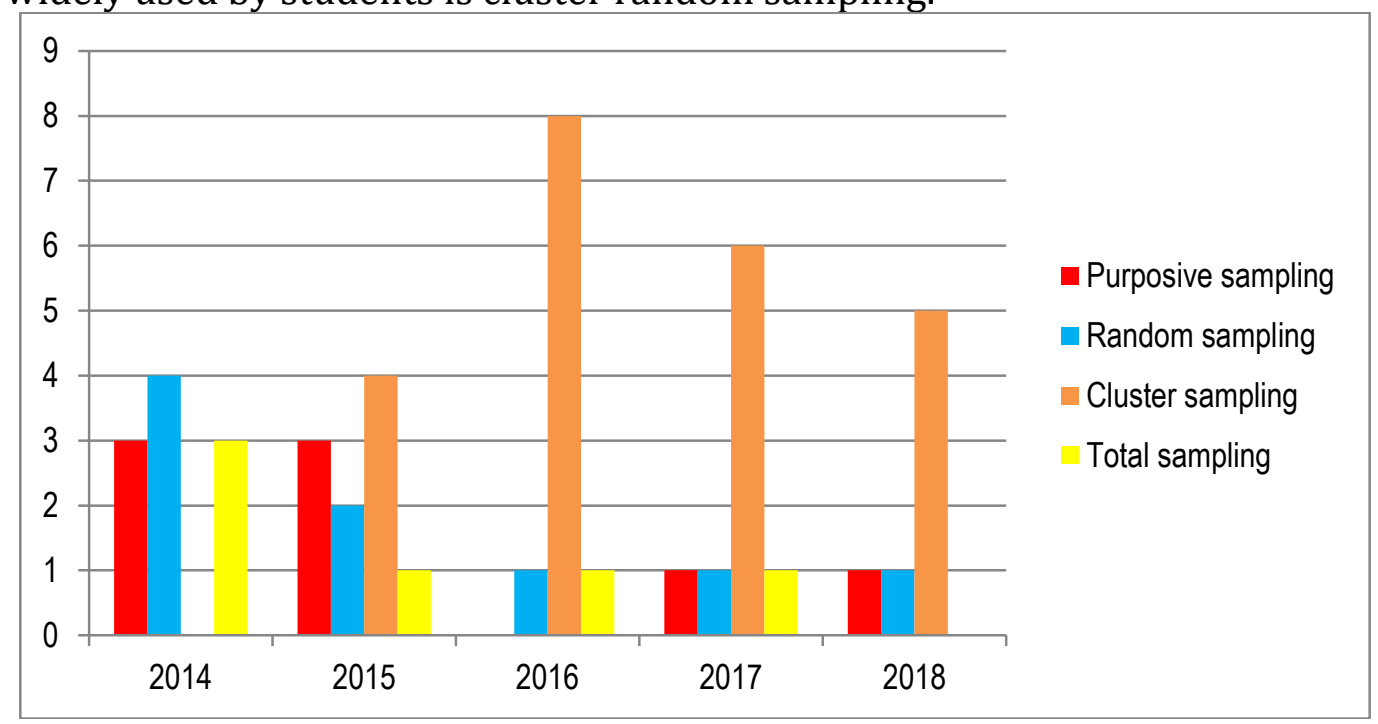

Figure 3. Research Sampling

\section{Research References}

Reference is a reference or something used by the information provider to support or strengthen the statement firmly. The following is the type of reference used by students in their research. The use of data sources or commonly referred to by students in 2014, uses articles more as their data source. It can be seen that the number of articles above amounts to 205 while the thesis amounts to 59 only.

In 2015 , the use of data sources or commonly referred to by students, uses articles more as their data source. It can be seen that the number of articles above amounts to 271 while the thesis amounts to 36 only. While in 2016, the use of data sources or commonly referred to by students, uses articles more as their data source. It can be seen that the number of articles above amounts to 254 while the thesis amounts to 55 only.

In 2017, students' data sources, commonly referred to by students, use articles more as their data source. It can be seen that the number of articles above amounts to 184 while the thesis amounts to 59 only. In 2018 students uses articles more as their data source. It can be seen that the number of articles above amounts to 220 while the thesis amounts to 52 only.

The several types of tables above, starting from 2014 to 2018 in the process of processing data and the amount of data obtained from each year, it can be concluded that the most used source or reference by students at the University of Cokroaminoto Palopo in obtaining data and information is using articles. During the research, researchers only found one reference from the book. 


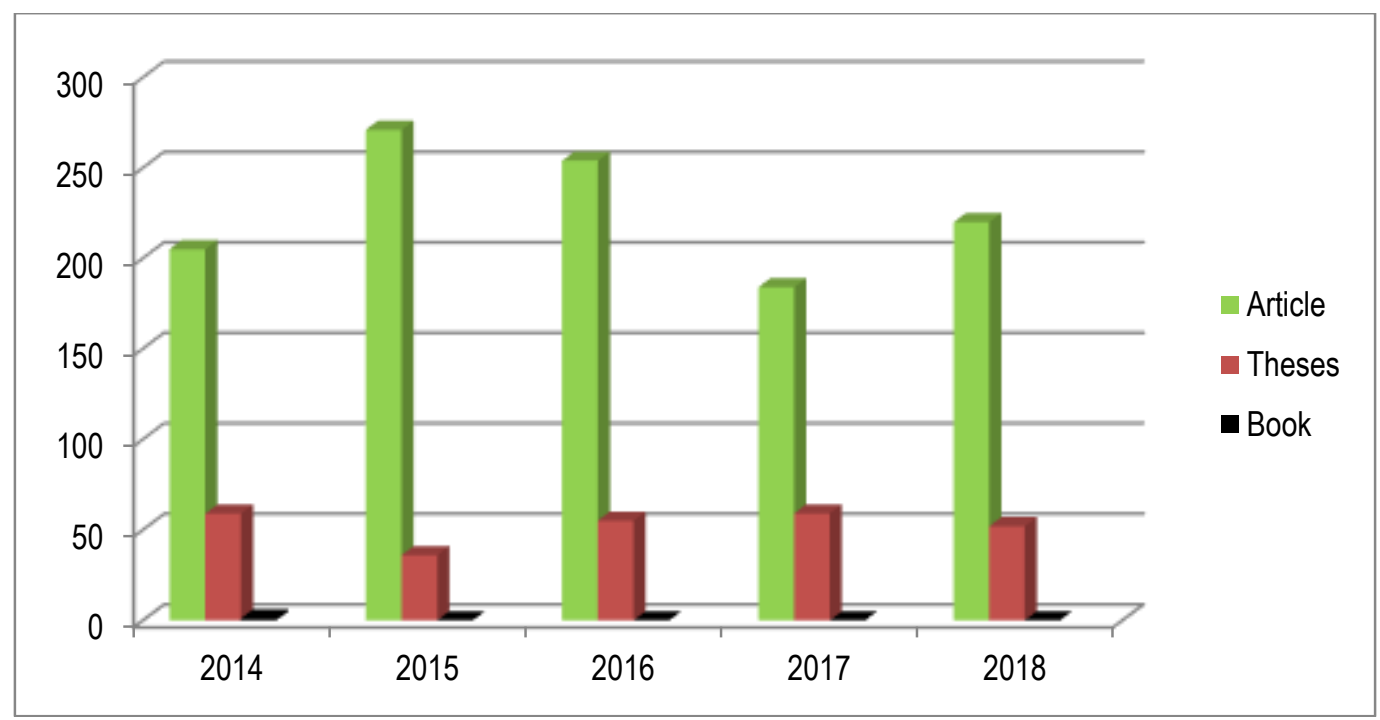

Figure 4. Graph About Research References

\section{Discussion}

Based on findings, many students still consider the vocabulary who are still lacking in memorizing and understanding vocabulary. The latest reading research on a person's reading ability is based on gender differences and the influence of family background in understanding EFL reading and how Japanese students' perspectives on visual and audio scaffolding in learning reading (Aditomo \& Hasugian, 2018; Stephen \& Kaiser, 2018). Whereas in this study, the theme of reading that is still widely discussed by students is applying the KWL and SQ3R methods in improving students 'reading skills, not only that there is also a theme of reading about the use of pre-questioning in developing students' reading skills. In conclusion, of the 12 titles raised by students about the theme of reading, all still relate to the latest research in the theory, namely how students develop the ability and understanding of reading students through the methods and techniques used by the students themselves.

The latest research on writing that year was about collaborative writing using digital photography (Ferdiansyah, 2018) and how to develop the quality of writing using several formulas (Akkoc, Qin, \& Karabacak, 2018). Compared to the latest research, the researchers do the theme of writing discussed by students regarding student performance in writing narrative text. The researcher can conclude that the latest research on writing is very diverse in form. Some use the type of text, methods, and techniques in developing the ability and interest in writing students.

According to Kurniawan \& Purwati (2018), in their findings explaining how to improve student oral fluency and improve students' speaking skills by telling stories (Nugraha, Marmoah \& Kurniati, 2018). When compared with current research, speaking skills also discusses how to develop students 'speaking skills using storytelling methods and students' anxiety or anxiety in speaking. So it can be concluded that research is now still discussing how to develop students' speaking skills by using several methods: storytelling and various other methods. Researchers are also still discussing anything that is still an obstacle for students to be able to talk about and anxiety faced by these students.

Yulisa (2018), in their study, discusses the latest research on listening, which deals with a significant correlation between listening strategy and comprehension listening through the implications for English teachers, course designers, students, and textbook 
authors. Research about listening was also about using the game method like "Odd One Out Game Discussion" to improve listening skills on English Subjects (Dahir, 2018). Compared with current research, research on listening in 2019 is about comparative studies of the ability to listen and about the effect of top-down strategies in teaching comprehension listening. So it can be concluded that the latest research on listening to date is still on how to find out students' understanding in listening by using several strategies and games applied by students in their research.

Grammatical errors compared to current research, researchers also found that current research also discusses grammatical errors made by students (Putri, Marmuah, \& Kurniati, 2018). So it can be concluded that recent research from 2018 to 2019 on grammar research is still researching grammatical errors and still the same.

Yanto \& Nugraha (2018) discussed vocabulary about developing second language vocabulary through videos and primary vocabulary plays in second language learning due to the importance of communicative competence and the acquisition process (Juanggo, 2018). Whereas when compared with current research, there are still many who still use vocabulary as their thesis title.

Özmen, Cephe, Kınık (2016), in their research, found that students mostly use quantitative in completing their thesis, especially experimental methods. Compared to current research, the quantitative method is still superior and is still widely used by students in processing data. The data source used by students to obtain information is that most of them use existing articles and theses. Many students use existing articles and theses because they get more info without reading for long periods through these sources. Not only that, most students prefer to look for sources in articles and thesis because they are made easier because the available data is immediately available without needing to search for much longer.

Several articles have discussed trends analysis in the previous study, including Özmen, Cephe, \& Kınık (2016). In their research, there are several types of equations in the study results, which are found in sampling and methods. The results show that students' sampling is most often used by students in purposive sampling, while in this study, the most types of sampling used by students are cluster random sampling. The method most widely used by students was also the quantitative method, with 24 in the previous study and 28 in this study.

Therefore, it can be concluded that students' themes are mostly vocabulary, while the least used by students, the theme is listening. Even in this type of method, it is still occupied by quantitative, which is the most widely used. From year to year, students still have an interest in choosing the themes and methods that are the same as in previous years, only the technique and the way they collect and the instruments used are different.

\section{Conclusion}

This research concluded that the trend is inconsistent. Each year it fluctuated as from 2014 to 2016, students widely use reading as the themes, but in 2017 to 2018 students shifted to vocabulary theme.. It also happens with the methods. Until 2018, many use the quantitative method as a research method that students use to analyze their data. Sometimes, the trend of its use increases, but there is a decrease even if a stable one does not occur in the following year. 


\section{References}

Aditomo, A., \& Hasugian, E. J. (2018). Indonesian Adolescents' EFL Reading Comprehension: Gender Differences and the Influence of Parental Background. Indonesian Journal of Applied Linguistics, $8(2)$. http://ejournal.upi.edu/index.php/IJAL/article/view/13279

Akkoç, A. B., Qin, J., \& Karabacak, E. (2018). The Effects of Explicit Instruction of Formulaic Language on EFL Argumentative Writing Quality. Indonesian Journal of Applied Linguistics, 8(2): 358-68. https://doi.org/10.17509/ijal.v8i2.13282

Dahir, D. (2018). Meningkatkan Kemampuan Menyimak (Listening Skill) Peserta Didik Kelas XII Sma Negeri 2 Kampar Melalui Pronunciation 'Odd One Out' Games Pada Teks Explanation Tahun Pelajaran 2017/2018. Jurnal Pendidikan Tambusai, 2(6), 1384-1400.

Ferdiansyah, S. (2018). Collaborative Narrative Writing: A Digital Photography Task in an Indonesian Islamic Secondary School. Indonesian Journal of Applied Linguistics, 8(2), 303-15. https://doi.org/10.17509/ijal.v8i2.13277

Juanggo, W. (2018). Investigating lexical diversity and lexical sophistication of productive vocabulary in the written discourse of Indonesian EFL learner. Indonesian Journal of Applied Linguistics, 8(2), 303-15. https://doi.org/10.17509/ijal.v8i2.13277

Kurniawan, E., \& Parwati, E. (2018). The Effect of a Narrative Structure and English Proficiency on University Students' Speaking Performance: Pausing Patterns. Indonesian Journal of Applied Linguistics, 8(2).

Nugraha, G. M., Marmoah, S. \& Kurniati, E. (2018). The Use of English Comics To Improve Students' Speaking Ability By Storytelling At Second Grade Students' At Smp N 8 Batanghari Jambi In Academic Year 2016/2017. JELT: Journal of English Language Teaching, 2(1), 162-70.

Ozmen, K. S., Cephe, P. T., Kinik, B. (2016). Trends in Doctoral Research On English Language Teaching in Turkey. (Online). https://files.eric.ed.gov/ fulltext/EJ1115055.pdf

Putri, R. T., Marmuah, S., \& Kurniati, E. (2018). An Analysis Of Students' Speaking Grammatical Errors At The Second Grade Sma N 10 Jambi Academic Year 2017/2018. Journal of English Language Teaching, 2. https://jelt.unbari.ac.id/index.php/jelt/article/ download/18/18

Stephens, M., \& Kaiser, M. R. (2018). A Comparison of Visual and Audio Scaffolds in L2 English Reading. Indonesian Journal of Applied Linguistics, 8(2). http://ejournal.upi.edu/index.php/IJAL/ article/view/13303

Yanto, E. S., \& Nugraha, S. I. (2018). Video Viewing as a Mediation of Learning ContentBased Vocabulary: Assisting Students in Understanding Disciplinary Vocabulary in Context. Indonesian Journal of Applied Linguistics, 8(2). http://ejournal.upi.edu/index.php/IJAL/article/view/13278

Yulisa, D. (2018). Learning to Listen: Listening Strategies and Listening Comprehension of Islamic Senior High School Students. Edukasi: Jurnal Pendidikan Dan Pengajaran, 5(1), 22-30. 